Immediate psychological effects of the COVID-19 quarantine in youth from Italy and Spain

\author{
Mireia Orgilés, $\mathrm{PhD} 1$ \\ Alexandra Morales, $\mathrm{PhD}_{1}$ \\ Elisa Delveccio, $\mathrm{PhD}_{2}$ \\ Claudia Mazzeschi, $\mathrm{PhD}_{2}$ \\ José P. Espada, $\mathrm{PhD} 1$ \\ 1Universidad Miguel Hernández (Spain) \\ ${ }_{2}$ Università degli Studi di Perugia (Italy)
}

\title{
Funding:
}

This work was supported by the Ministry of Science and Innovation of Spain and the European Regional Development Fund (PSI2017-85493-P).

Correspondence address: Mireia Orgilés. Miguel Hernández University. Department of Health Psychology. Avda. de la Universidad s/n, Elche, 03202, Alicante, Spain. Email: morgiles@umh.es

Brief Title: Psychological effects of quarantine on youths 


\begin{abstract}
Background: The COVID-19 quarantine has affected more than 860 million children and adolescents worldwide but, to date, no study has been developed to examine the psychological impact on their lives. The present study aims to examine for the first time the emotional impact of the quarantine on children and adolescents from Italy and Spain, two of the most affected countries by COVID-19.

Methods: 1,143 parents of Italian and Spanish children aged 3 to 18 years completed a survey providing information about how the quarantine affects their children and themselves, compared to before the home confinement.

Findings: $85.7 \%$ of the parents perceived changes in their children's emotional state and behaviors during the quarantine. The most frequent symptoms were difficulty concentrating (76.6\%), boredom (52\%), irritability (39\%), restlessness $(38.8 \%)$, nervousness (38\%), feelings of loneliness (31.3\%), uneasiness (30.4\%), and worries (30.1\%), and Spanish parents reported more symptoms than Italians. As expected, children of both countries used monitors more frequently, spent less time doing physical activity, and slept more hours during the quarantine. Furthermore, when family coexistence during quarantine became more difficult, the situation was more serious, and the level of stress was higher, parents tended to report more emotional problems in their children.

Interpretation: The quarantine impacts considerably on Italian and Spanish youth, reinforcing the need to detect children with emotional and behavioral problems as early as possible to improve their psychological well-being.
\end{abstract}




\section{Immediate psychological effects of the COVID-19 quarantine in youth from Italy and Spain}

The outbreak of the 2019 coronavirus disease (COVID-19) emerged in the city of Wuhan (China) in December 2019. Motivated by its rapid spreading, the World Health Organization (WHO) declared it a pandemic on March 11 20201. Italy and Spain are two of the most affected countries worldwide, with, respectively, more than 18.800 and 16.000 reported deaths, on April 112 since its spread. In Spain, the pandemic is deadlier in relation to the number of inhabitants, with 310 deaths per million inhabitants, followed by Italy, with 284 deaths per million inhabitants, as of April 10 2. Following the Chinese government's retarding the spread of the COVID-19, quarantine was implemented in Italy and Spain, among other countries, starting on March 10 in Italy and five days later in Spain. School closure was mandatory and gathering in public spaces, with certain exceptions, was prohibited. However, the effect of closing schools as a measure to decrease virus transmission is inconclusive. According to a systematic review of studies focused on other previous coronavirus outbreaks, school closure did not seem to have a very determining effect compared to other social distancing measures and, following some COVID-19 modeling studies, school closure may only reduce between 2 and $4 \%$ of deaths 3 .

This is the first time that a quarantine to control a pandemic has been implemented in Italy and Spain, as well as in most countries worldwide. Therefore, there is a lack of conclusive studies providing data on how this measure can affect children and adolescents. Regarding the specific psychological consequences of COVID-19 and the measures to cope with them, few studies have been published. The psychological impact on the Chinese population after two weeks of quarantine was rated as moderate or brief by $53.8 \%$ of the 1210 participants in a study with adults from 194 cities in China4. Symptoms with a moderate to severe severity of depression were reported by $16.5 \%$ of participants, anxiety in $28.8 \%$, and stress in $8.1 \%$. The results of a study with 4,607 adults aged 17 to 90 years from 31 regions of China, however, reported slight changes in the frequency with which participants experienced negative and positive emotions before and after the COVID-19 imposed quarantine. Rather, some benefits were found, reporting fewer sleep problems, fewer aggressive behaviors, and less alcohol and tobacco use during the quarantine. As the authors of the study point out, among other reasons, the quarantine was imposed just before the Chinese New Year holidays when the majority of the population was at home with their family, thus having social support to reduce stress5. Concerning the specific stressors affecting the population during the quarantine, a review of 24 studies highlights as main stressors the duration of the quarantine, the fear of infection, frustration and boredom, and not having adequate information or clear guidelines from public authorities; as main stressors after the quarantine, having financial problems and the stigma in people who were infected or exposed to the disease were reported6.

To date, no studies have examined how the quarantine declared due to COVID-19 may affect children's and adolescents' emotional or behavioral well-being. Some previous studies suggest that the effects may be troublesome. A review of 190 studies with American population concluded that, compared to vacation periods and weekends, by being more structured, class days give children more opportunities to be physically active, spend less time in front of screens, and regulate their sleep schedules.7 Post-traumatic stress is estimated to be four times higher in children who have been in quarantine compared to those who have not, and their likelihood of presenting acute stress disorder, adjustment disorder, and grief is also higher8. Some authors have reflected on the possible effects of the COVID-19 quarantine on children and adolescents. Wang and colleagues 9 highlight the need for awareness of the quarantine's potential effects on children's mental health, and the importance for 
governments, non-governmental organizations, the community, schools, and parents to act to reduce the possible effects of this situation. Special attention should be paid to children and adolescents who are separated from their caregivers who are infected or suspected of being infected, and those whose caregivers are infected or have died, because they are more vulnerable to psychological problems. 10

It is very important to identify childhood mental health problems as soon as possible, differentiating normal and pathological reactions through the use of screening tools that may indicate the need for intervention.10,11However, so far, we have not found any study that examines the effect in children and adolescents of the quarantine imposed by COVID-19. The available studies have been carried out with adult population - hence, the results cannot be extrapolated to child population - and with Chinese population - whose cultural differences with the West make it difficult to generalize their findings. This study is the first to determine the immediate psychological responses in children and adolescents of the quarantine imposed to put an end to COVID-19. The main objective of the study is to examine the emotional wellbeing of Italian and Spanish children aged between 3 and 18 who are in quarantine as a measure imposed by governments to prevent the transmission of COVID-19. Specifically, the aim is to know: a) the immediate psychological responses in children and adolescents during the quarantine, $b$ ) the emotional impact of the quarantine on the child's primary caregiver, c) the relationship between the parents' emotional state and their children's immediate psychological responses, and d) the change in children's habits.

\section{Participants}

\section{Method}

Table 1 reports sample characteristics and differences in sociodemographic variables by country. Of the 1,143 participants, $62.3 \%$ were recruited from 94 cities of Italy, and the rest from 87 cities of Spain. The respondents were aged 18 to 66 and were the primary caregiver of children aged 3 to 18 (47.5\% were females). Most children were not diagnosed with a physical or psychological problem (89\%). The caregivers' educational level was relatively high; more than half of them $(61.9 \%)$ had attended college to study a degree, a Master's degree or a PhD program, and only $6.9 \%$ had basic studies. The mothers' and fathers' current employment situation varied. In many cases, the parents had a full-time job or smart-worked. Around 5\% reported having lost their job because of the COVID-19 situation. More than half of the participants (69.4\%) reported having some at-risk friends or family, but they did not live with them during the quarantine; only $9 \%$ belonged to an at-risk group.

The Italian and Spanish samples were equivalent, except for respondents' educational level, the mothers' or fathers' current employment situation, respondents' situation concerning COVID-19, children's age, and the proportion of children with physical or psychological problems. In the Spanish sample, there was a higher proportion of parents with postgraduate or doctoral studies or with secondary education than in the Italian sample. Compared to Spain, a higher proportion of Italian women were employed ( 84.3 vs. $94.8 \%$ ), and they had part-time jobs ( $8.4 \%$ vs. $18.9 \%)$. Italian children were slightly older than the Spanish ones ( 9.40 years vs. 8.55 years), although the effect size was very low. 
Table 1.

Sample characteristics and differences by country

\begin{tabular}{|c|c|c|c|c|c|c|}
\hline & $\begin{array}{c}\text { Total } \\
(n=1,143)\end{array}$ & $\begin{array}{c}\text { Italy } \\
(n=712)\end{array}$ & $\begin{array}{c}\text { Spain } \\
(n=431)\end{array}$ & Testa & $p$ & $\begin{array}{c}\text { Effect } \\
\text { sizeb }\end{array}$ \\
\hline \multicolumn{7}{|l|}{ Parents } \\
\hline Female, $N(\%)$ & $1,006(88)$ & $627(88.1)$ & $379(87.9)$ & .004 & .94 & - \\
\hline Age, $M(S D)$ & $42.30(6.17)$ & $42.38(6.64)$ & $42.17(5.32)$ & .59 & .55 & - \\
\hline \multicolumn{7}{|l|}{ Educational level, $N(\%)$} \\
\hline Doctoral or Master's Degree & $213(18.6)$ & $107(15)$ & $106(24.6)$ & 48.89 & $<.001$ & .20 \\
\hline Undergraduate & $495(43.3)$ & $297(41.7)$ & $198(45.9)$ & & & \\
\hline Secondary school & $356(31.1)$ & $270(37.9)$ & $86(20)$ & & & \\
\hline Primary school & $79(6.7)$ & $38(5.4)$ & $41(9.5)$ & & & \\
\hline \multicolumn{7}{|l|}{ Monthly family income (euros) } \\
\hline Up to 999 & $64(6.4)$ & $33(5.3)$ & $31(8.3)$ & 9.03 & .06 & - \\
\hline Between 1,000 and 1,999 & $277(27.7)$ & $164(26.2)$ & $113(30.1)$ & & & \\
\hline Between 2,000 and 2,999 & $307(30.7)$ & $209(33.4)$ & $98(26.1)$ & & & \\
\hline Between 3,000 and 4,999 & $275(27.5)$ & $169(27)$ & $106(28.3)$ & & & \\
\hline 5,000 or more & $78(7.7)$ & $51(8.1)$ & $27(7.2)$ & & & \\
\hline \multicolumn{7}{|l|}{ Mother's current employment situation } \\
\hline Self-employed & $180(16)$ & $118(16.8)$ & $62(14.5)$ & 55.93 & $<.001$ & .22 \\
\hline Part-time & $168(14.9)$ & $132(18.9)$ & $36(8.4)$ & & & \\
\hline Full-time & $285(25.2)$ & $176(25.2)$ & $109(25.5)$ & & & \\
\hline Unemployed & $103(9.1)$ & $36(5.1)$ & $67(15.7)$ & & & \\
\hline Lost job due to COVID-19 & $57(5.1)$ & $30(4.3)$ & $27(6.3)$ & & & \\
\hline Smart-working & $260(23.1)$ & $157(22.5)$ & $103(24.1)$ & & & \\
\hline Other & $74(6.6)$ & $50(7.2)$ & $24(5.5)$ & & & \\
\hline \multicolumn{7}{|l|}{ Father's current employment situation } \\
\hline Self-employed & $279(25)$ & $184(26.6)$ & $95(22.4)$ & 43.31 & $<.001$ & .20 \\
\hline Part-time & $28(2.5)$ & $15(2.2)$ & $13(3.1)$ & & & \\
\hline Full-time & $503(45.1)$ & $335(48.5)$ & $168(39.5)$ & & & \\
\hline Unemployed & $32(2.9)$ & $15(2.2)$ & $17(4)$ & & & \\
\hline Lost job due to COVID-19 & $51(4.6)$ & $17(2.5)$ & $34(8)$ & & & \\
\hline Smart-working & $200(17.9)$ & $120(17.4)$ & $80(18.8)$ & & & \\
\hline Other & $22(2)$ & $4(0.6)$ & $18(4.2)$ & & & \\
\hline \multicolumn{7}{|l|}{ Your situation concerning COVID-19 } \\
\hline I belong to a risk group & $103(9)$ & $41(5.8)$ & $62(14.4)$ & 34.07 & $<.001$ & .17 \\
\hline $\begin{array}{l}\text { People belonging to a risk group } \\
\text { live with me }\end{array}$ & $151(13.2)$ & $94(13.2)$ & $57(13.2)$ & & & \\
\hline $\begin{array}{l}\text { Friends or family are at-risk } \\
\text { population (not living with us) }\end{array}$ & $793(69.4)$ & $501(70.4)$ & $292(67.7)$ & & & \\
\hline $\begin{array}{l}\text { I do not know anyone who belongs } \\
\text { to an at-risk population }\end{array}$ & $96(8.4)$ & $76(10.6)$ & $20(4.7)$ & & & \\
\hline \multicolumn{7}{|l|}{ The house where you live has, $N(\%)$} \\
\hline Only windows & $102(8.9)$ & $25(3.5)$ & $77(17.9)$ & 167.97 & $<.001$ & .38 \\
\hline Garden & $445(38.9)$ & $368(51.7)$ & $77(17.9)$ & & & \\
\hline Terrace & $272(23.8)$ & $151(21.1)$ & $121(28.1)$ & & & \\
\hline Balcony & $286(25)$ & $141(19.9)$ & $145(33.5)$ & & & \\
\hline Another exit & $38(3.3)$ & $27(3.8)$ & $11(2.6)$ & & & \\
\hline Square meters home, $M(S D)$ & $\begin{array}{l}126.11 \\
(63.22)\end{array}$ & $\begin{array}{r}123.14 \\
(62.29)\end{array}$ & $\begin{array}{r}124.99 \\
(62.86)\end{array}$ & .77 & .43 & - \\
\hline \multicolumn{7}{|l|}{ Children } \\
\hline Female, $N(\%)$ & $543(47.5)$ & $351(49.3)$ & $192(44.5)$ & 2.42 & .11 & - \\
\hline Age, $M(S D)$ & $9.08(4.22)$ & $9.40(4.46)$ & $8.55(3.73)$ & 3.32 & .001 & .07 \\
\hline $\begin{array}{l}\text { Physical or psychological problems. } \\
\text { Yes, } N(\%)\end{array}$ & $126(11)$ & $52(7.3)$ & $74(17.2)$ & 26.64 & $<.001$ & .15 \\
\hline $\begin{array}{l}\text { Is your child receiving treatment for } \\
\text { that problem? Yes, } N(\%)\end{array}$ & $96(8.4)$ & $42(5.9)$ & $54(12.5)$ & 45.32 & $<.001$ & .19 \\
\hline
\end{tabular}




\section{Procedure}

Participants were recruited via social networks, as face-to-face contact was not allowed. An online survey was created ad hoc and distributed in each country using a snowball sampling strategy. Before completing the survey, information about the objectives of the study was provided and informed consent was requested. Data were collected for 15 days in both countries. The approval of the Ethics Board of the authors' institution was obtained for the research.

\section{Survey development}

Scientific literature related to the psychological impact of quarantine was reviewed and questionnaires applied in previous studies with adult population were considered for creating the survey. It was structured in four sections, collecting information on: a) sociodemographics of parents and children (see Table 1), b) parental perception on how quarantine emotionally affects children through 31 symptoms ranging from 1 (much less compared to before quarantine) to 5 (much more compared to before quarantine), c) parent's perception of family coexistence during quarantine, severity of the situation caused by coronavirus for the family well-being, and parents' stress, on a five-point scale, and d) children's routines: time of screen use, physical activity, and hours of sleep during quarantine compared to before.

\section{Data Analyses}

All analyses were performed with SPSS v.26. Descriptive statistics were run to analyze participants' sociodemographic variables and other variables of interest for the study. Differences between Italy and Spain in sociodemographic variables, children's psychological responses, emotional impact on the child's primary caregiver, and the child's routines were analyzed using Chi-square ( $\left.\chi_{2}\right)$ (categorical variables) and $t$-test for independent samples (continuous variables). Paired-sample $t$-tests were carried out to compare the mean hours of sleep before and during quarantine for each country. Cohen's $d$ was calculated to report effect size for statistically significant differences - .2 is considered small, .5 medium, and .8 large 12 . Odds Ratio $(O R)$ was reported for $2 \times 2$ tables. Cramer's $V$ was calculated as a measure of association between multi-categorical variables, and interpreted as follows: $>0.25$ very strong, $>0.15$ strong, $>0.10$ moderate, $>0.05$ weak, and $>0$ none or very weak13. Spearman correlations were calculated to analyze the relationship between the primary caregivers' emotional effects due to COVID-19 and their children's psychological responses.

\section{Results}

\section{Parental perception of the emotional effects of the quarantine on their children}

Nine hundred and eighty parents $(85.7 \% ; 83.8 \%$ in Italy and $88.9 \%$ in Spain) observed changes in their children's emotional state and behaviors during the quarantine. The most common changes (present in at least $20 \%$ of the responses) were that, during quarantine, their children had more difficulty concentrating $(76.6 \%)$, felt more bored than usual (52\%), were more irritable (39\%), more restless (38.8\%), more nervous (38\%), felt lonelier $(31.3 \%)$, were more uneasy $(30.4 \%)$, more worried $(30.1 \%)$, more likely to argue with the rest of the family $(29.7 \%)$, more dependent on them (28\%), more anxious $(28.4 \%)$, angrier $(25.9 \%)$, more reluctant $(24.7 \%)$, sadder $(23.3 \%)$, afraid of COVID-19 infection $(23.1 \%)$, more worried when someone left the house (22\%), and ate more than usual (21.9\%). Table 2 details the percentage of the primary caregivers who perceived changes in their children's emotional state and behaviors during the quarantine and the differences between Italy and Spain. 
Table 2

Primary caregivers' perception of the emotional and behavioral effects of the quarantine in their children

\begin{tabular}{|c|c|c|c|c|c|c|c|c|}
\hline & \multicolumn{2}{|c|}{ Total } & \multicolumn{2}{|c|}{ Italy } & \multicolumn{2}{|c|}{ Spain } & \multirow[t]{2}{*}{$\chi^{2}$} & \multirow{2}{*}{$\begin{array}{c}O R \\
(95 \% \mathrm{CI})\end{array}$} \\
\hline & $N$ & $\%$ & $n$ & $\%$ & $n$ & $\%$ & & \\
\hline My child is worried & 344 & 30.1 & 226 & 31.7 & 118 & 27.4 & 2.43 & $.81(.62,1.05)$ \\
\hline My child is restless & 443 & 38.8 & 247 & 34.7 & 196 & 45.5 & $13.15 * * *$ & $1.57(1.232)$ \\
\hline My child is anxious & 325 & 28.4 & 146 & 20.5 & 179 & 15.7 & $58.32 * * *$ & $2.75(2.11,3.58)$ \\
\hline My child is sad & 266 & 23.3 & 189 & 26.5 & 77 & 17.9 & $11.32 * * *$ & $.80(.44, .81)$ \\
\hline My child has nightmares & 126 & 11 & 62 & 8.7 & 64 & 14.8 & $10.32 * * *$ & $1.28(1.26,2.65)$ \\
\hline My child is reluctant & 282 & 24.7 & 192 & 27 & 90 & 20.9 & $5.34 *$ & $.71(.53, .95)$ \\
\hline My child feels lonely & 358 & 31.3 & 280 & 39.3 & 78 & 18.1 & $56.24 * * *$ & $.34(.25, .45)$ \\
\hline My child wakes up frequently & 138 & 12.1 & 70 & 9.8 & 68 & 15.8 & $8.94 * *$ & $1.71(1.20,2.45)$ \\
\hline My child sleeps little & 125 & 10.9 & 52 & 7.3 & 31.3 & 16.9 & $25.58 * * *$ & $2.58(1.77,3.77)$ \\
\hline My child is very indecisive & 131 & 11.5 & 62 & 8.7 & 69 & 16 & $14.10 * * *$ & $1.98(1.38,2.88)$ \\
\hline My child is uneasy & 347 & 30.4 & 184 & 25.8 & 163 & 37.8 & $18.21 * * *$ & $1.74(1.35,2.25)$ \\
\hline My child is nervous & 434 & 38 & 243 & 34.1 & 191 & 44.3 & $11.82 * * *$ & $1.53(1.20,1.96)$ \\
\hline My child is afraid to sleep alone & 197 & 17.2 & 94 & 13.2 & 103 & 23.9 & $21.53 * * *$ & $2.06(1.51,2.81)$ \\
\hline $\begin{array}{l}\text { My child argues with the rest of the } \\
\text { family }\end{array}$ & 339 & 29.7 & 165 & 23.2 & 174 & 40.4 & $38.05 * * *$ & $2.24(1.73,2.90)$ \\
\hline My child is very quiet & 126 & 11 & 102 & 14.3 & 24 & 5.6 & $20.99 * * *$ & $.35(.22, .56)$ \\
\hline My child cries easily & 195 & 17.1 & 97 & 13.6 & 98 & 22.7 & $15.76^{* * *}$ & $1.86(1.36,2.54)$ \\
\hline My child is angry & 296 & 25.9 & 157 & 22.1 & 139 & 32.3 & $14.55 * * *$ & $1.68(1.28,2.20)$ \\
\hline My child asks about death & 155 & 13.6 & 102 & 14.3 & 53 & 12.3 & .94 & $.83(.58,1.19)$ \\
\hline My child feels frustrated & 213 & 18.6 & 113 & 15.9 & 100 & 23.2 & $9.51 * *$ & $1.60(1.18,2.16)$ \\
\hline My child is bored & 596 & 52.1 & 383 & 53.8 & 213 & 49.4 & 2.05 & $.83(.66,1.06)$ \\
\hline My child is irritable & 446 & 39 & 260 & 36.5 & 186 & 43.2 & $4.97 *$ & $1.32(1.03,1.68)$ \\
\hline My child has sleeping difficulties & 195 & 17.1 & 90 & 7.9 & 105 & 9.2 & $26.06 * * *$ & $2.22(1.63,3.04)$ \\
\hline My child has no appetite & 98 & 8.6 & 48 & 6.7 & 50 & 11.6 & $8.08 * *$ & $1.81(1.19,2.75)$ \\
\hline My child is easily alarmed & 138 & 12.1 & 78 & 11 & 60 & 13.9 & 2.22 & $1.31(.91,1.88)$ \\
\hline $\begin{array}{l}\text { My child has difficulty } \\
\text { concentrating }\end{array}$ & 875 & 76.6 & 577 & 81 & 298 & 69.1 & $21.17 * * *$ & $1.90(1.44,2.51)$ \\
\hline $\begin{array}{l}\text { My child is afraid of COVID-19 } \\
\text { infection }\end{array}$ & 264 & 23.1 & 164 & 23 & 100 & 23.2 & .004 & $1.01(.76,1.34)$ \\
\hline My child is very dependent on us & 320 & 28 & 163 & 22.9 & 157 & 36.4 & $24.39 * * *$ & $1.93(1.48,2.51)$ \\
\hline $\begin{array}{l}\text { My child has physical complaints } \\
\text { (headache, stomach ache ...) }\end{array}$ & 159 & 13.9 & 72 & 10.1 & 87 & 20.2 & $22.74 * * *$ & $2.24(1.60,3.15)$ \\
\hline My child has behavioral problems & 185 & 16.2 & 57 & 8 & 128 & 29.7 & $93.13 * * *$ & $4.84(3.45,6.82)$ \\
\hline My child eats a lot & 250 & 21.9 & 142 & 19.9 & 108 & 25.1 & $4.10^{*}$ & $1.34(1.01,1.78)$ \\
\hline $\begin{array}{l}\text { My child worries when one of us } \\
\text { leaves the house }\end{array}$ & 251 & 22 & 121 & 17 & 130 & 30.2 & $27.16^{* * *}$ & $2.10(1.58,2.80)$ \\
\hline
\end{tabular}

Note. $\chi_{2}=$ chi-square; $O R=$ Odds Ratio; $\mathrm{CI}=$ Confidence Interval ${ }^{*} p<.05 .{ }^{*} p p<.01 . * * * p<.001$.

Spanish children were significantly more psychologically affected than Italian children during the quarantine $\left(88.9 \%\right.$ vs. $83.8 \%, \chi^{2}=5.52, p=.01, O R=1.53,95 \%$ CI $\left.[1.07,2.20]\right)$. Compared to Italian children, Spanish children had more behavioral problems $(O R=4.84$, $95 \%$ CI $[3.45,6.82])$, were more anxious $(O R=2.75,95 \%$ CI $[2.11,3.58])$, slept less $(O R=$ 
$2.58,95 \%$ CI $[1.77,3.77])$, were more likely to argue with the rest of the family $(O R=2.24$, $95 \%$ CI $[1.73,2.90])$, had more physical complaints $(O R=2.24,95 \%$ CI $[1.60,3.15])$, more sleeping difficulties $(O R=2.22,95 \% \mathrm{CI}[1.63,3.04])$, and were more worried when one of parents left the house (for example, to buy groceries) $(O R=2.10,95 \%$ CI $[1.58,2.80])$. These differences had an OR above 2. Other differences in Spanish and Italian children's emotional state and behaviors during the quarantine are detailed in Table 2. Compared to Spanish children, Italians felt sadder $(O R=.60,95 \% \mathrm{CI}[.44, .81])$, were more reluctant $(O R=.71$, $95 \% \mathrm{CI}[.53, .95])$, and felt lonelier $(O R=.34,95 \%$ CI $[.25, .45])$ during the quarantine.

\section{Family coexistence during the quarantine, perception of severity and stress due to COVID-19}

Primary caregivers reported that family coexistence during the quarantine was found to be moderately easy $(M=3.68, S D=1.98$, range $=1-5)$. Only $11.4 \%$ reported that family coexistence during the quarantine was difficult or very difficult, and more than half $(61.8 \%)$ informed that family coexistence was easy or very easy. The neutral option was selected by $26.8 \%$. The parents perceived the current situation due to COVID-19 was quite serious $(M=$ $3.63, S D=.96$, range $=1-5)$. Approximately one half $(55.4 \%)$ perceived that the situation was serious or very serious. Only $11.6 \%$ considered that the current situation was a little serious or not serious. The rest $(33 \%)$ perceived the situation was somewhat serious. Parental level of stress was moderate $(M=3.18, S D=1.02$, range $=1-5)$. Approximately one-third of the parents $(35.4 \%)$ reported being stressed or very stressed, and $39.4 \%$ chose the option somewhat stressed. One in four $(25.2 \%)$ parents indicated that they did not feel stressed because of the current situation.

When comparing the data of Italy and Spain, no differences were observed in the perception of how easy it is for the family to live together during the quarantine $(t=.84, p=$ $.40)$, how serious the current situation caused by the coronavirus is for their well-being and their family well-being $(t=.1 .10, p=.27)$, and the level of parental stress $(t=.03, p=.26)$.

\section{Relationship between primary caregivers' perception of COVID-19 and their children's immediate psychological responses during the quarantine}

The primary caregivers' perception of how easy it is for the family to live together during the quarantine was related to 11 of the 31 child symptoms. When family coexistence during the quarantine was rated as more difficult, the parents tended to rate their children as more restless, more anxious and uneasy, more nervous, more likely to argue with the rest of the family, angrier, more frustrated, more irritable, with more difficulty concentrating, presenting more behavioral problems, and less likely to be quiet (compared to before home confinement). Spearman correlations were indirect (except for being quiet) and low, ranging from -.06 to -.15 .

Primary caregivers' perception of the seriousness of the current situation caused by the coronavirus for their well-being and their family's well-being was associated with 15 of the 31 child symptoms. Caregivers who perceived the current situation as more serious for their family's well-being tended to report that, during quarantine, their children were more concerned, more restless, more anxious, sadder, lonelier, more nervous and uneasy, more likely to argue with the rest of the family, cried more easily, were angrier, more bored, had more difficulty concentrating, were more afraid of COVID-19 infection, and more worried when one of them left the house (compared to before home confinement). Spearman correlations were direct and low, ranging from .06 to .15.

Primary caregivers' level of stress was related to 25 of the 31 child symptoms. Parents who perceived themselves as more stressed by the situation tended to report that, during quarantine, their children were more worried, more restless, more anxious, sadder, more 
reluctant, lonelier, woke up more frequently, more indecisive, more uneasy, more nervous, more afraid to sleep alone, more likely to argue with the rest of the family, cried more easily, were angrier, more frustrated, more bored, more irritable, had more difficulty concentrating and sleeping, were more easily alarmed, were more afraid of COVID-19 infection, were more dependent on them, had more behavioral problems. and were more worried when one of them left the house (compared to before home confinement). Spearman correlations were direct, ranging from low $(\rho=.07)$ to moderate $(\rho=.26)$. However, parental stress was indirectly related to being quiet, suggesting that parents who are more stressed perceive their children as being less quiet, although this correlation was low $(\rho=-.06)$.

Table 3.

Spearman correlations between primary caregivers' perception of emotional and behavioral effects on their children and their perception of the situation due to COVID-19

\begin{tabular}{|c|c|c|c|}
\hline Child symptoms & $\begin{array}{l}\text { How easy is living } \\
\text { together in the } \\
\text { family? }\end{array}$ & $\begin{array}{l}\text { How serious do you } \\
\text { perceive the current } \\
\text { situation? }\end{array}$ & $\begin{array}{l}\text { How stressed } \\
\text { do you feel? }\end{array}$ \\
\hline My child is worried & -.003 & $.124 * *$ & $.126 * *$ \\
\hline My child is restless & $-.098^{* *}$ & $.109^{* *}$ & $.235 * *$ \\
\hline My child is anxious & $-.063 *$ & $.158 * *$ & $.238^{* *}$ \\
\hline My child is sad & -.017 & $.060 *$ & $.155^{* *}$ \\
\hline My child has nightmares & -.017 & -.010 & .019 \\
\hline My child is reluctant & -.050 & .052 & $.118^{* *}$ \\
\hline My child is feels lonely & .004 & $.074 *$ & $.099_{* *}$ \\
\hline My child wakes up frequently & .011 & .054 & $.094 * *$ \\
\hline My child is sleeps little & -.011 & .051 & .046 \\
\hline My child is very indecisive & -.022 & .053 & $.116 * *$ \\
\hline My child is uneasy & $-.078^{* *}$ & $.072 *$ & $.200 * *$ \\
\hline My child is nervous & $-.120 * *$ & $.110^{* *}$ & $.260 * *$ \\
\hline My child is afraid to sleep alone & -.026 & .048 & $.106^{* *}$ \\
\hline $\begin{array}{l}\text { My child argues with the rest of } \\
\text { the family }\end{array}$ & $-.155^{* *}$ & $.071 *$ & $.188 * *$ \\
\hline My child is very quiet & $.069 *$ & -.025 & $-.063 *$ \\
\hline My child is cries easily & -.032 & $.061 *$ & $.089^{* *}$ \\
\hline My child is angry & $-.107 * *$ & $.100 * *$ & $.196 * *$ \\
\hline My child asks about death & .001 & .003 & .047 \\
\hline My child is feels frustrated & $-.084 * *$ & .028 & $.092 * *$ \\
\hline My child is bored & -.016 & $.137 * *$ & $.183^{* *}$ \\
\hline My child is irritable & $-.133 * *$ & $.066 *$ & $.174 * *$ \\
\hline $\begin{array}{l}\text { My child is has sleeping } \\
\text { difficulties }\end{array}$ & -.038 & .039 & $.075 *$ \\
\hline My child has no appetite & .022 & .007 & .002 \\
\hline My child is easily alarmed & -.042 & .046 & $.106^{* * *}$ \\
\hline $\begin{array}{l}\text { My child has difficulty } \\
\text { concentrating }\end{array}$ & $-.076 * *$ & $.073 *$ & $.139^{* * *}$ \\
\hline $\begin{array}{l}\text { My child is afraid of COVID-19 } \\
\text { infection }\end{array}$ & .040 & $.140 * *$ & $.091^{* *}$ \\
\hline My child is very dependent on us & -.057 & .057 & $.129^{* *}$ \\
\hline $\begin{array}{l}\text { My child has physical complaints } \\
\text { (headache, stomach ache ...) }\end{array}$ & -.041 & -.001 & .036 \\
\hline My child has behavioral problems & $-.139 * *$ & .025 & $.102 * *$ \\
\hline My child eats a lot & -.021 & .048 & .042 \\
\hline $\begin{array}{l}\text { My child worries when one of us } \\
\text { leaves the house }\end{array}$ & -.009 & $.089 * *$ &, $074 *$ \\
\hline
\end{tabular}

$* p<.05 . * * p<.01$ 


\section{Children's patterns of use of screens, daily physical activity, and hours of sleep before and during the quarantine}

Table 5 indicates that, during the quarantine, children spend more time daily using screens such as iPads, TVs, mobiles, or computers $\left(\chi_{2}=519.60^{* * *}, p<.001\right.$, Cramer's $V=$ $.30)$, spend less time doing physical activity $\left(\chi_{2}=22.08, p<.001\right.$, Cramer's $\left.V=.19\right)$, and tend to sleep a bit more (mean hours) $(t=-8.08 p<.001, d=0.20)$, compared to before this period. These changes in children's routines during the quarantine were confirmed in both countries.

During the quarantine, Italian children spent more time using screens $\left(\chi_{2}=449.25, p<\right.$ .001 , Cramer's $V=.35)$, less time daily doing physical activity $\left(\chi_{2}=161.94, p<.001\right.$, Cramer's $V=.21)$, and more time sleeping during the week $(t=-68.08 p<.001, d=0.22)$, compared to before the quarantine. Spanish children spent more time using screens $\left(\chi_{2}=\right.$ $142.53, p<.001$, Cramer's $V=.25$ ), less time daily doing physical activity ( $\chi^{2}=93.62, p<$ .001 , Cramer's $V=.20)$, and more time sleeping during the week $(t=-2.98 p=.003, d=$ $0.17)$, compared to before quarantine.

Differences between Italy and Spain were found in the use of screens during the quarantine $\left(\chi_{2}=28.80, p<.001\right.$, Cramer's $\left.V=.15\right)$. During the quarantine, Spanish children tended to spend more time using screens than did Italian children, such that $89.7 \%$ of the Spanish children used screens for at least 60 minutes per day, whereas $81.6 \%$ of the Italian children did so. No differences between Spain and Italy in psychical activity during the quarantine were found $\left(\chi_{2}=3.59, p=.60\right)$, suggesting that Spanish children (more active before the quarantine) stopped being active. Spanish children tended to sleep more hours (mean hours during the week) than did Italian children $(t=-4.53, p<.001, d=0.28)$.

Table 4.

Children's patterns of use of screens, daily physical activity, and hours of sleep before and during the quarantine

\begin{tabular}{|c|c|c|c|c|c|c|}
\hline \multirow[b]{2}{*}{$\begin{array}{l}\text { Children's activity } \\
\text { patterns }\end{array}$} & \multicolumn{2}{|c|}{ Total } & \multicolumn{2}{|c|}{ Italy } & \multicolumn{2}{|c|}{ Spain } \\
\hline & $\begin{array}{l}\text { Before } \\
\text { quarantine }\end{array}$ & $\begin{array}{c}\text { During } \\
\text { quarantine }\end{array}$ & $\begin{array}{l}\text { Before } \\
\text { quarantine }\end{array}$ & $\begin{array}{c}\text { During } \\
\text { quarantine }\end{array}$ & $\begin{array}{l}\text { Before } \\
\text { quarantine }\end{array}$ & $\begin{array}{c}\text { During } \\
\text { quarantine }\end{array}$ \\
\hline \multicolumn{7}{|c|}{ Use of screens (minutes) } \\
\hline Less than 30 & $253(22.1)$ & $39(3.4)$ & $129(18.1)$ & $32(4.5)$ & $124(28.8)$ & $7(1.6)$ \\
\hline From 30 to 60 & $403(35.3)$ & $136(11.9)$ & $252(35.4)$ & $99(13.9)$ & $151(35)$ & $37(8.6)$ \\
\hline From 60 to 90 & $262(22.9)$ & $208(18.2)$ & $173(24.3)$ & $135(19)$ & $89(20.7)$ & $73(16.9)$ \\
\hline $\begin{array}{l}\text { From } 90 \text { to } 120 \\
\text { From } 120 \text { to } 180\end{array}$ & $\begin{array}{r}125(10.9) \\
63(5.5)\end{array}$ & $\begin{array}{l}214(18.7) \\
205(17.9)\end{array}$ & $\begin{array}{r}86(12.1) \\
47(6.6)\end{array}$ & $\begin{array}{l}129(18.1) \\
101(14.2)\end{array}$ & $\begin{array}{r}39(9) \\
16(3.7)\end{array}$ & $\begin{array}{r}85(19.7) \\
104(24.2)\end{array}$ \\
\hline $\begin{array}{l}\text { More than } 180 \\
\text { Physical activity } \\
\text { (minutes per day) }\end{array}$ & $37(3.3)$ & $341(29.9)$ & $25(3.5)$ & $216(30.3)$ & $12(2.8)$ & $125(29)$ \\
\hline Less than 30 & 155 (13.6) & $635(55.6)$ & $125(17.6)$ & $404(56.7)$ & $30(7)$ & $231(53.6)$ \\
\hline From 30 to 60 & $369(32.3)$ & $336(29.4)$ & $251(35.2)$ & $198(27.8)$ & $118(27.4)$ & $138(32)$ \\
\hline From 60 to 90 & $320(28)$ & $108(9.3)$ & 177 (24.9) & $67(9.4)$ & $143(33.2)$ & $41(9.5)$ \\
\hline From 90 to 120 & $150(13.1)$ & $38(3.3)$ & $83(11.7)$ & $27(3.9)$ & $67(15.5)$ & $11(2.6)$ \\
\hline From 120 to 180 & $83(7.3)$ & $12(1)$ & $36(5.1)$ & $8(1.1)$ & $47(10.9)$ & $4(0.9)$ \\
\hline More than 180 & $66(5.7)$ & $14(1.2)$ & $40(5.5)$ & $8(1.1)$ & $26(6)$ & $6(1.4)$ \\
\hline $\begin{array}{l}\text { Hours of sleep/week } \\
M(S D)\end{array}$ & $9.08(1.45)$ & $9.39(1.57)$ & $8.86(1.56)$ & $9.22(1.65)$ & $9.44(1.16)$ & $9.66(1.38)$ \\
\hline
\end{tabular}




\section{Discussion}

This study is the first one developed to examine the psychological impact of the COVID-19 quarantine on children and adolescents. Italy and Spain are two of the most affected countries worldwide by COVID-19, and the emotional well-being of youth needs to be explored to provide parents and caregivers with guidelines to reduce the impact of the quarantine on their children.

Results indicate that $85.7 \%$ of the parents reported changes in their children's emotional state and behaviors during the quarantine. The most frequent symptom was difficulty concentrating, with $76.6 \%$ of the parents reporting this symptom. Boredom, irritability, restlessness, nervousness, feelings of loneliness, being more uneasy and more worried was reported by more than $30 \%$ of parents. Results by country show that Spanish children were more affected than Italian children in most symptoms. Although more research is needed to clarify this finding, the permission given by the Italian government to parents on March 31 to take under-18-year-old youths for a short walk (access to parks, gardens and all kind of public spaces is still not allowed) might explain the differences between Spain and Italy. Whereas in Italy, after three weeks of home confinement, children are allowed to go out for a short walk close to home accompanied by one adult, in Spain, children can only go outside for a justified reason. Furthermore, many more Italian homes have gardens compared to Spanish homes (52 vs. 18\%), so this provides children with the opportunity to be more active, benefiting their mental wellbeing. These differences in rules and the characteristics of the homes of the two both countries may explain why Spanish children show a worse behavioral and emotional response to the quarantine. Staying at home without the chance to go outside may increase responses of anxiety and other related problems such as sleep problems, physical complaints, and worries, and also behavioral problems that involve the family, such arguing with other relatives, maybe because the children need to be more physically active. In contrast, Italian children are perceived by their parents as sadder, more reluctant and lonely, maybe due to the longer duration of the quarantine in Italy compared to Spain. As expected, routines also changed during the quarantine in the children of both countries, spending more time using screens, less time doing physical activity, and sleeping more hours. For instance, during the quarantine, only $14.8 \%$ of the youth practice at least 60 minutes of physical activity, as recommended by the WHO for children between 5 and 17 years old, compared to before the quarantine, when that percentage reached 54.1\%. According to a review of studies that observed differences in habits between weekdays and vacation days, the present study found more healthy routines in youth before the quarantine?. This finding is also in line with other reflections that warn about the consequences of children's home confinement, specifically affecting not only their mental well-being but also their weight status and the risk of increasing screen time 14.

Although only $11.4 \%$ of the Italian and Spanish parents informed that family coexistence was difficult or very difficult, most parents perceived the situation due to COVID-19 as serious or very serious, and one-third of the parents reported being stressed or very stressed, with no differences between the two countries. Furthermore, parents' perception of COVID-19 seems to be related to their child's psychological symptoms during the quarantine. When family coexistence during the quarantine was more difficult, the situation was more serious, or the level of stress was higher, parents tended to report more emotional problems in their children; specifically, primary caregiver level of stress was related to 25 of the 31 child symptoms. Although a causal relationship cannot be confirmed, it is expected that children's behavioral problems will negatively affect the family climate, and also, parents with a high level of stress may apply more inconsistent discipline to their children. 
In conclusion, the COVID-19 quarantine impacts considerably on Italian and Spanish youth's lives, and most parents perceive changes in their children's emotional state and behaviors during the quarantine compared to before the quarantine. Spanish children show more emotional and behavioral symptoms compared to Italian children, as reported by their parents, possibly because Italian youth have more opportunities to be more physically active. The emotional and behavioral symptoms of children from both countries seem to be positively related to the parents' well-being, specifically to their level of stress. On the basis of these findings, we can conclude that children and parents are both affected by such a stressful situation as the quarantine. The present study has as the main limitation that it was not possible to access reports by children due to restrictions of the quarantine, so information was only reported by parents. Despite this limitation, this study is the first providing data on the psychological repercussion of the COVID-19 quarantine on children and adolescents. Future studies should follow the psychological responses of youth during the quarantine to detect the need for intervention as early as possible.

\section{References}

1. World Health Organization (WHO). WHO director-general's opening remarks at the media briefing on COVID-19 - 11 march 2020. https://www.who.int/dg/speeches/detail/whodirector-general-s-opening-remarks-at-the-media-briefing-on-covid-19---11-march-2020. Updated 2020. Accessed 04/11, 2020.

2. European Centre for Disease Prevention and Control. Covid-19. https://qap.ecdc.europa.eu/public/extensions/COVID-19/COVID-19.html. Updated 2020. Accessed 11 April, 2020.

3. Viner RM, Russell SJ, Croker H, et al. School closure and management practices during coronavirus outbreaks including COVID-19: A rapid systematic review. Lancet Child Adolesc Health. 2020(DOI:https://doi.org/10.1016/S2352-4642(20)30095-X).

4. Wang C, Pan R, Wan X, et al. Immediate psychological responses and associated factors during the initial stage of the 2019 coronavirus disease (COVID-19) epidemic among the general population in china. Int J Environ Res Public Health. 2020;17(5):1729doi:10.3390/ijerph17051729.

5. Li J, Yang A, Dou K, Wang L, Zhang M, Lin X. Chinese public's knowledge, perceived severity, and perceived controllability of the COVID-19 and their associations with emotional and behavioural reactions, social participation, and precautionary behaviour: A national survey. BMC Public Health. 2020:doi:10.21203/rs.3.rs-16572/v1https://www.researchsquare.com/article/rs-16572/v1.

6. Brooks SK, Webster RK, Smith LE, et al. The psychological impact of quarantine and how to reduce it: Rapid review of the evidence. Lancet. 2020;395(10227):912-920.

7. Brazendale K, Beets MW, Weaver RG, et al. Understanding differences between summer vs. school obesogenic behaviors of children: The structured days hypothesis. Int J Behav Nutr Phys Act. 2017;14(1).

8. Sprang G, Silman M. Posttraumatic stress disorder in parents and youth after health-related disasters. Disaster Med Public Health Preparedness. 2013;7(1):105-110. 
9. Wang G, Zhang Y, Zhao J, Zhang J, Jiang F. Mitigate the effects of home confinement on children during the COVID-19 outbreak. Lancet. 2020;395(10228):945-947.

10. Liu JJ, Bao Y, Huang X, Shi J, Lu L. Mental health considerations for children quarantined because of COVID-19. Lancet Child Adolesc Health.

2020:https://www.thelancet.com/journals/lanchi/article/PIIS2352-4642(20)300961/fulltext.

11. Espada JP, Orgilés M, Piqueras JA, Morales A. Buenas prácticas en la atención psicológica infanto-juvenil ante el COVID-19 [good practices in child and adolescent psychological care due to COVID-19 ]. Clínica y Salud. in press.

12. Cohen J. Statistical power analysis for the behavioral sciences. 2nd edition ed. Hillsdale, NJ: Erlbaum; 1988.

13. Akoglu H. User's guide to correlation coefficients. Turk J Emerg Med. 2018;18(3):91-93.

14. Lancet Child Adolesc Health. Pandemic school closures: Risks and opportunities. Lancet Child Adolesc Health. 2020:https://doi.org/10.1016/S2352-4642(20)30105-X. 